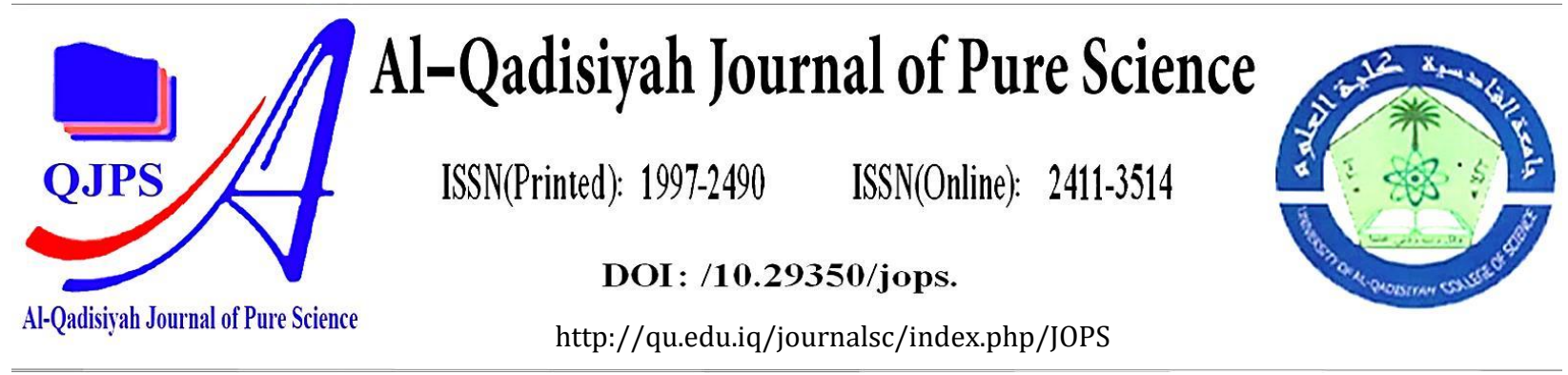

\title{
Concentrations of Polychlorinated Biphenyls (PCBs) in Phragmites australis of Shatt AL-Arab River, Basrah Governorate South of Iraq
}

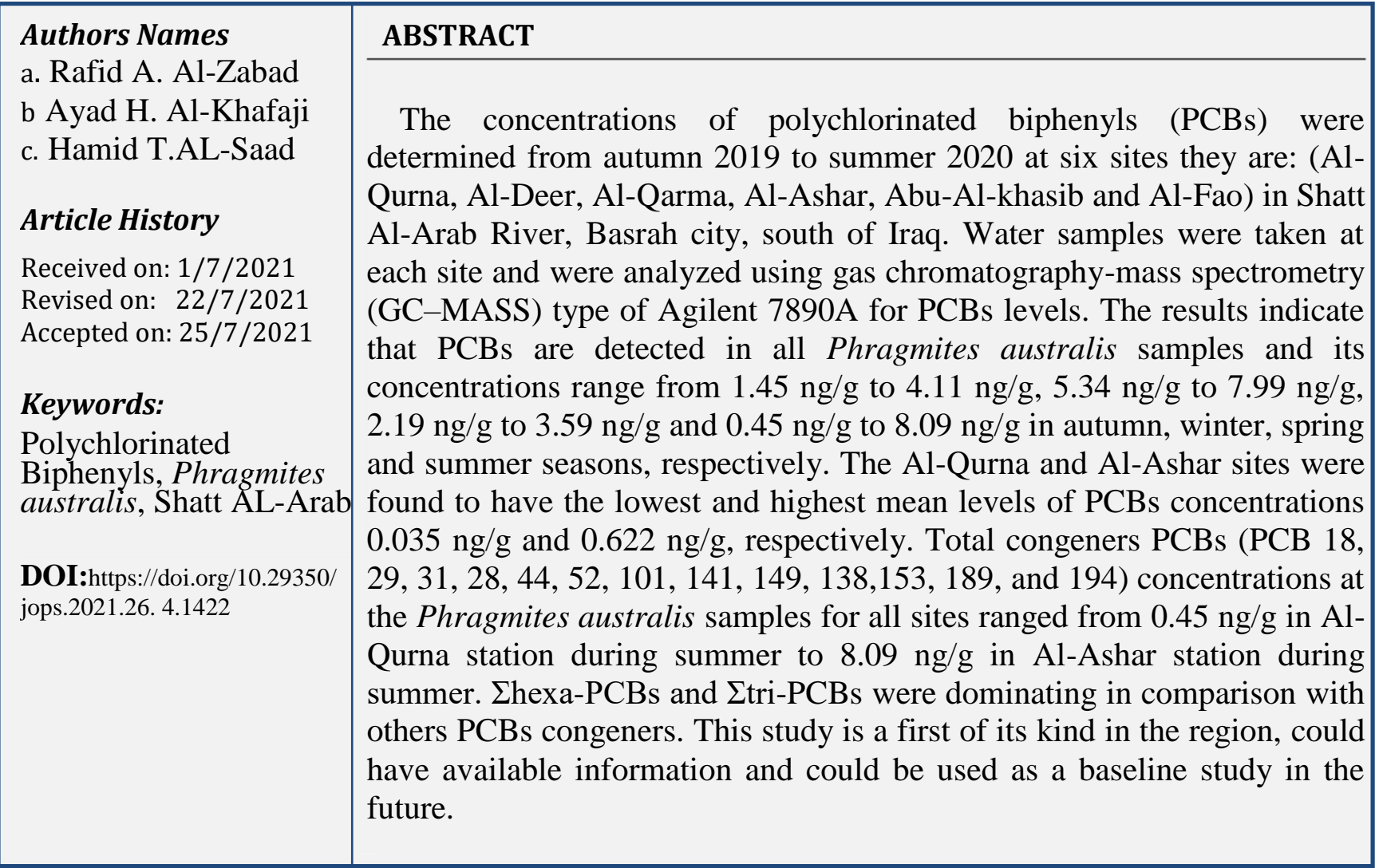

\section{INTRODUCTION}

The Shatt al Arab River is formed after the confluence of the Euphrates and the Tigris Rivers near the city of Al-Qurna in southern Iraq. Shatt Al-Arab estuary region is shared between Iran and Iraq. In addition to the Euphrates and Tigris Rivers, the Karkheh and the Karun sub-basins contribute water to the Shatt Al-Arab River. Both the Karkheh and the Karun Rivers originate in the Zagros Mountains in Iran and discharge to the Shatt Al-Arab River. Shatt Al-Arab River receives many

\footnotetext{
${ }^{a, b}$ Department of Biology, college of Science, Basrah University, Iraq.

${ }^{\circ}$ College of Marine Science, Basrah University, Basrah, Iraq

Email: rafidahmed_27@yahoo.com
} 
pollutants when it passes through Basrah City due to many human activities and factories that factories, which have been discharged their wastewater into the river without treatments. The Shatt AlArab River is used as a sink for wastes from agricultural, industry and other human activities due to its flow and ecological nature [3].

PCBs are synthetic, aromatic compounds formed in such a manner that the hydrogen atoms on the biphenyl molecule (two benzene rings bonded together by a single carbon-carbon bond) may be replaced by up to 10 chlorine atoms related to biphenyl, which is a molecule composed of two benzene rings with a chemical formula of $\mathrm{C}_{12} \mathrm{H}_{10-\mathrm{x}} \mathrm{Cl}_{\mathrm{x}}$, where $\mathrm{X}=1-10$, (Figure 1) [5]. Their physicochemical properties cause them to be persistent in the environment and exhibit tendencies for bioaccumulation, biomagnifications, long-range transport and deposition in places far removed from emission sources. In addition, they cause chronic toxicity and are ubiquitous in ecosystems and humans [18]. PCBs' negative effects on humans include impaired reproduction, cancer, neuro-developmental effects in infants, endocrine disruption and immunotoxicity [7]. PCBs stimulate changes in the DNA sequence [20] and severe liver damage [17].

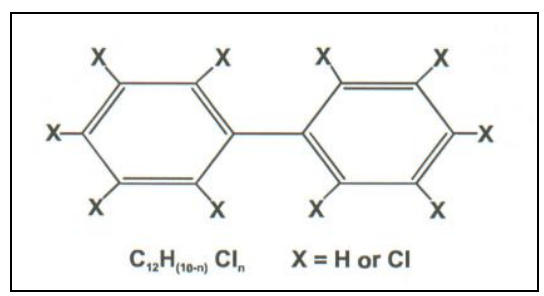

Figure (1): The chemical formula of PCBs

PCBs can be released into the environment through runoff, volatilization, oil leakage, waste discharges, and dry and wet deposition [19,30]. PCBs may be released into the environment from hazardous waste sites and leaks from electrical transformers containing PCBs. A small amount of PCBs may remain dissolved in the water, but most of them stick to organic molecules and sediments. PCBs accumulate in water, plant, fish and marine mammals (whale, seal). It can reach levels thousands of times higher than those found in water [23].

The Phragmites australis is a biennial plant and it is called the common reed, It rise about $3 \mathrm{~m}$ tall ,has long leaves and it is from the Anchored plants, the roots of the plant are in the water while most of the plant body is outside of the water [1]. It can grow in organic sediment of high or low concentrations [29]. Phyto-remediation is a form of biological treatment, which means using particular plants that can reduce pollution levels through metabolic mechanisms that lead to the removal, sequestration or analysis of various pollutants [6,28]. According to Greipsson [14], phytoremediation is a technique used by plants to absorb pollutants from sediment and water.

The present work aimed to determine the concentrations of PCBs for Phragmites australis samples in Shatt Al-Arab River in Basrah city, south of Iraq. This project is the first work that reports PCBs concentrations in Iraq. Therefore, the main objective of the present study in Shatt Al-Arab River was to Determine the concentrations and types of PCBs in six stations along the Shatt Al-Arab River, Basrah province, southern Iraq. 


\section{MATERIALS AND METHODS}

Phragmites australis samples were collected seasonally during the period from autumn 2019 to summer 2020 at six stations in Shatt Al-Arab River in Basrah city for analysis and estimation the concentration of some polychlorinated biphenyls (PCBs). The stations are Al-Qurna (St.1), Al-Deer (St.2), Al-Qarma (St.3), Al-Ashar (St.4), Abu-Alkhasib (St.5) and Al-Fao (St.6), (Figure 2). Global Positioning System (GPS) instrument is used to fix the positions of these stations, (Table 1).

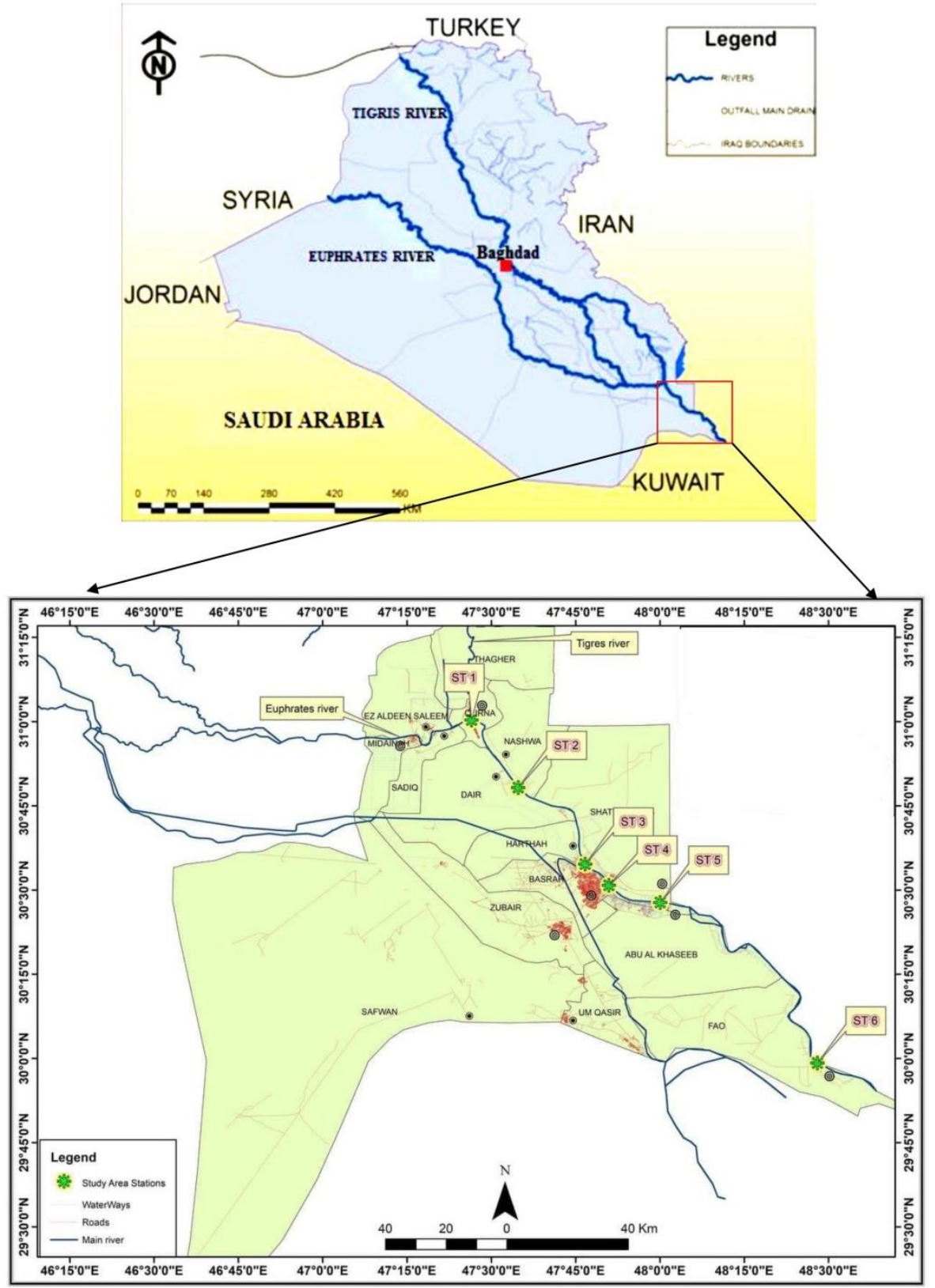

Figure (2): Map of the study stations

Table (1): Latitude and longitude of the Locations in the study area. 


\begin{tabular}{|c|c|c|}
\hline Longitude and Latitude & Location Name & Location No. \\
\hline $\begin{array}{l}\text { N } 31.00422^{\circ} \\
\text { E047.44138 }\end{array}$ & Al-Qurna & St.1 \\
\hline $\begin{array}{l}\mathrm{N} 30.80363^{\circ} \\
\mathrm{E} 047.58006^{\circ}\end{array}$ & Al-Deer & St.2 \\
\hline $\begin{array}{l}\mathrm{N} 30.57690^{\circ} \\
\mathrm{E} 047.77743^{\circ}\end{array}$ & Al-Qarma & St.3 \\
\hline $\begin{array}{l}\mathrm{N} 30.51234^{\circ} \\
\mathrm{E} 047.84884^{\circ}\end{array}$ & Al-Ashar & St.4 \\
\hline $\begin{array}{l}\text { N } 30.46259^{\circ} \\
\text { E048.00092 }\end{array}$ & Abu-Alkhasib & St.5 \\
\hline $\begin{array}{l}\text { N 29.98571 } \\
\text { E048.46718 }\end{array}$ & Al-Fao & St.6 \\
\hline
\end{tabular}

Phragmites australis samples were collected by hands (the whole plant), which are located on the side of the river and contact with the river water after washing it with river water to remove suspended substances. The Phragmites australis samples were kept in aluminum foil and put in plastic bags until transfer to the laboratory. The samples of Phragmites australis were dried for several days at laboratory temperature, the plant was cutting into small pieces and grind by an electric blender device, subsequently sieved with a sieve with holes diameter (63) microns. Five grams (dry weight) of Phragmites australis were taken and transferred in a cellulose thimble to extract PCBs compounds by Soxhlet Intermittent Extraction. The samples-standard mixture was subjected for $18 \mathrm{~h}$ with $50 \mathrm{~mL}$ of Dichloromethan $(\mathrm{DCM}) / \mathrm{n}$-hexane $(1: 1 \mathrm{v} / \mathrm{v})$. Saponification was performed for two $\mathrm{h}$, then use the separating funnel to separate the PCBs compounds. The concentrated extract was purified on a column packed from bottom to top with Glass Wool, two grams each of anhydrous $\mathrm{Na}_{2} \mathrm{SO}_{4}$, silica gel, and copper powder. Copper powder was used to remove sulfur from the extracts in order to avoid sulfur interferences when using gas chromatography. The extract transformed to vial and saved until measurement by (GC-MASS) type of Agilent 7890A. PCBs were extracted from phragmites australis samples according to Vorkamp et al., [27] method.

\subsection{Statistical analysis}

Analysis Of Variance (One -Way ANOVA) was applied by statistical software, Statistical Package for Social Science (SPSS) ver.17.0 to identify the existence of spatial and temporal significant differences. The relationship between the parameters and indices was calculated using the Pearson's Correlation Coefficients.

\section{RESULTS AND DISCUSSION}

The PCBs concentrations in the Phragmites australis are displayed in (Tables 2-5). The result show the concentrations of $\Sigma 13 \mathrm{PCBs}$ compounds in Phragmites australis samples ranged from $(0.45$ $\mathrm{ng} / \mathrm{g})$ in the Al-Qurna station during the summer a mean of $(0.035)$ to $(8.09 \mathrm{ng} / \mathrm{g})$ was founded in the Al-Ashar station during summer a mean of (0.622) (Figure 3). The results of this study showed that PCBs compounds decreased during the summer while increased during the winter, except Al-Qarma 
and Al-Ashar stations. concentrations of PCBs in the Al-Qurna station ranged between $0.45 \mathrm{ng} / \mathrm{g}$ to $6.85 \mathrm{ng} / \mathrm{g}$, Al- Deer station concentrations ranged between $1.82 \mathrm{ng} / \mathrm{g}$ to $5.34 \mathrm{ng} / \mathrm{g}$, Al-Qarma station ranged between $3.59 \mathrm{ng} / \mathrm{g}$ to $7.42 \mathrm{ng} / \mathrm{g}$, Al-Ashar station ranged between $3.33 \mathrm{ng} / \mathrm{g}$ to $8.09 \mathrm{ng} / \mathrm{g}$, Abu Al-khasib station ranged between $3.39 \mathrm{ng} / \mathrm{g}$ to $6.09 \mathrm{ng} / \mathrm{g}$. The values in Al-Faw station ranged between $2.19 \mathrm{ng} / \mathrm{g}$ to $7.99 \mathrm{ng} / \mathrm{g}$ (Figure 4,5).

Table (2): Concentrations of PCBs (ng/g d.w) in Phragmites australis samples at the studied stations during autumn season.

\begin{tabular}{ccccccc}
$\begin{array}{c}\text { Compound } \\
\text { Name }\end{array}$ & $\begin{array}{c}\text { Al- } \\
\text { Qurna }\end{array}$ & $\begin{array}{c}\text { Al- } \\
\text { Deer }\end{array}$ & $\begin{array}{c}\text { Al- } \\
\text { Qarma }\end{array}$ & $\begin{array}{c}\text { Al- } \\
\text { Ashar }\end{array}$ & $\begin{array}{c}\text { Abu-Al } \\
\text { Khasib }\end{array}$ & $\begin{array}{c}\text { Al- } \\
\text { Fao }\end{array}$ \\
\hline PCB 18 & 0.05 & 0.28 & 0.27 & 0.67 & 0.47 & 0.47 \\
PCB 29 & 0.02 & 0.00 & 0.00 & 0.00 & 0.16 & 0.00 \\
PCB 31 & 0.86 & 0.07 & 0.43 & 1.56 & 0.39 & 0.34 \\
PCB 28 & 0.03 & 0.15 & 0.01 & 0.03 & 0.09 & 0.15 \\
PCB 44 & 0.01 & 0.02 & 0.02 & 0.02 & 0.02 & 0.01 \\
PCB 52 & 0.24 & 0.52 & 0.57 & 1.62 & 0.61 & 0.65 \\
PCB 101 & 0.06 & 0.51 & 1.21 & 0.21 & 0.48 & 0.65 \\
PCB 141 & 0.00 & 0.02 & 0.00 & 0.00 & 0.42 & 0.00 \\
PCB 149 & 0.05 & 0.09 & 0.00 & 0.00 & 0.00 & 0.00 \\
PCB 138 & 0.02 & 0.00 & 0.00 & 0.00 & 0.00 & 0.00 \\
PCB 153 & 0.02 & 0.00 & 0.00 & 0.00 & 0.36 & 0.00 \\
PCB 189 & 0.05 & 1.56 & 0.84 & 0.00 & 0.00 & 0.90 \\
PCB 194 & 0.04 & 0.41 & 0.32 & 0.00 & 1.04 & 0.65 \\
TOTAL PCBs & 1.45 & 3.63 & 3.67 & 4.11 & 4.04 & 3.82 \\
Mean & 0.112 & 0.279 & 0.282 & 0.316 & 0.311 & 0.294 \\
\hline
\end{tabular}

Table (3): Concentrations of PCBs (ng/g d.w) in Phragmites australis samples at the studied stations during winter season.

\begin{tabular}{ccccccc}
$\begin{array}{c}\text { Compound } \\
\text { Name }\end{array}$ & $\begin{array}{c}\text { Al- } \\
\text { Qurna }\end{array}$ & $\begin{array}{c}\text { Al- } \\
\text { Deer }\end{array}$ & $\begin{array}{c}\text { Al- } \\
\text { Qarma }\end{array}$ & $\begin{array}{c}\text { Al- } \\
\text { Ashar }\end{array}$ & $\begin{array}{c}\text { Abu-Al } \\
\text { Khasib }\end{array}$ & $\begin{array}{c}\text { Al- } \\
\text { Fao }\end{array}$ \\
\hline PCB 18 & 0.92 & 1.02 & 0.91 & 1.77 & 0.81 & 0.87 \\
PCB 29 & 0.00 & 0.00 & 0.00 & 0.00 & 0.00 & 0.00 \\
PCB 31 & 0.37 & 0.65 & 0.58 & 0.96 & 0.00 & 0.00 \\
\hline PCB 28 & 0.53 & 0.00 & 0.00 & 0.00 & 0.00 & 0.00 \\
PCB 44 & 0.15 & 0.39 & 0.56 & 0.89 & 0.05 & 0.14 \\
\hline PCB 52 & 0.63 & 0.35 & 0.47 & 0.34 & 0.82 & 0.91 \\
PCB 101 & 0.92 & 0.00 & 0.80 & 0.00 & 0.00 & 0.94 \\
\hline PCB 141 & 0.00 & 0.30 & 0.60 & 0.68 & 0.00 & 0.73 \\
PCB 149 & 0.98 & 0.82 & 0.94 & 0.97 & 1.35 & 1.27 \\
\hline PCB 138 & 0.35 & 0.61 & 0.99 & 0.88 & 1.21 & 1.36 \\
\hline PCB 153 & 0.43 & 0.45 & 0.00 & 0.62 & 1.16 & 0.99 \\
\hline PCB 189 & 0.69 & 0.00 & 0.00 & 0.00 & 0.00 & 0.00 \\
\hline PCB 194 & 0.88 & 0.75 & 1.04 & 0.77 & 0.69 & 0.78 \\
TOTAL PCBs & 6.85 & 5.34 & 6.89 & 7.88 & 6.09 & 7.99 \\
\hline Mean & 0.527 & 0.411 & 0.530 & 0.606 & 0.468 & 0.615 \\
\hline
\end{tabular}


Table (4): Concentrations of PCBs (ng/g d.w) in Phragmites australis samples at the studied stations during spring season.

\begin{tabular}{ccccccc}
$\begin{array}{c}\text { Compound } \\
\text { Name }\end{array}$ & $\begin{array}{c}\text { Al- } \\
\text { Qurna }\end{array}$ & $\begin{array}{c}\text { Al- } \\
\text { Deer }\end{array}$ & $\begin{array}{c}\text { Al- } \\
\text { Qarma }\end{array}$ & $\begin{array}{c}\text { Al- } \\
\text { Ashar }\end{array}$ & $\begin{array}{c}\text { Abu-Al } \\
\text { Khasib }\end{array}$ & $\begin{array}{c}\text { Al- } \\
\text { Fao }\end{array}$ \\
\hline PCB 18 & 0.42 & 0.43 & 0.47 & 0.44 & 0.45 & 0.29 \\
PCB 29 & 0.01 & 0.00 & 0.00 & 0.00 & 0.03 & 0.00 \\
PCB 31 & 0.04 & 0.04 & 0.05 & 0.04 & 0.04 & 0.03 \\
PCB 28 & 0.03 & 0.04 & 0.05 & 0.05 & 0.03 & 0.02 \\
PCB 44 & 0.03 & 0.03 & 0.04 & 0.03 & 0.03 & 0.02 \\
\hline PCB 52 & 0.05 & 0.05 & 0.06 & 0.05 & 0.05 & 0.04 \\
PCB 101 & 0.34 & 0.35 & 0.38 & 0.36 & 0.36 & 0.24 \\
\hline PCB 141 & 0.92 & 0.94 & 1.02 & 0.95 & 0.97 & 0.63 \\
PCB 149 & 0.12 & 0.13 & 0.14 & 0.13 & 0.13 & 0.08 \\
\hline PCB 138 & 0.32 & 0.33 & 0.36 & 0.34 & 0.34 & 0.22 \\
\hline PCB 153 & 0.55 & 0.57 & 0.62 & 0.58 & 0.59 & 0.38 \\
\hline PCB 189 & 0.32 & 0.33 & 0.36 & 0.33 & 0.34 & 0.22 \\
PCB 194 & 0.03 & 0.03 & 0.04 & 0.03 & 0.03 & 0.02 \\
\hline TOTAL PCBs & 3.18 & 3.27 & 3.59 & 3.33 & 3.39 & 2.19 \\
\hline Mean & 0.245 & 0.252 & 0.276 & 0.256 & 0.261 & 0.168 \\
\hline
\end{tabular}

Table (5): Concentrations of PCBs (ng/g d.w) in Phragmites australis samples at the studied stations during the summer season.

\begin{tabular}{ccccccc}
\hline $\begin{array}{c}\text { Compound } \\
\text { Name }\end{array}$ & $\begin{array}{c}\text { Al- } \\
\text { Qurna }\end{array}$ & $\begin{array}{c}\text { Al- } \\
\text { Deer }\end{array}$ & $\begin{array}{c}\text { Al- } \\
\text { Qarma }\end{array}$ & $\begin{array}{c}\text { Al- } \\
\text { Ashar }\end{array}$ & $\begin{array}{c}\text { Abu-Al } \\
\text { Khasib }\end{array}$ & $\begin{array}{c}\text { Al- } \\
\text { Fao }\end{array}$ \\
\hline PCB 18 & 0.05 & 0.24 & 0.98 & 1.07 & 0.59 & 0.63 \\
PCB 29 & 0.00 & 0.00 & 0.00 & 0.00 & 0.00 & 0.00 \\
PCB 31 & 0.01 & 0.02 & 0.08 & 0.09 & 0.06 & 0.07 \\
PCB 28 & 0.02 & 0.04 & 0.09 & 0.11 & 0.08 & 0.05 \\
PCB 44 & 0.01 & 0.02 & 0.07 & 0.08 & 0.04 & 0.05 \\
PCB 52 & 0.01 & 0.03 & 0.12 & 0.13 & 0.07 & 0.08 \\
PCB 101 & 0.05 & 0.19 & 0.81 & 0.87 & 0.48 & 0.51 \\
PCB 141 & 0.12 & 0.52 & 2.13 & 2.32 & 1.28 & 1.37 \\
PCB 149 & 0.02 & 0.07 & 0.28 & 0.31 & 0.17 & 0.18 \\
\hline PCB 138 & 0.04 & 0.18 & 0.75 & 0.82 & 0.45 & 0.48 \\
\hline PCB 153 & 0.07 & 0.31 & 1.29 & 1.39 & 0.77 & 0.83 \\
PCB 189 & 0.04 & 0.18 & 0.75 & 0.82 & 0.45 & 0.48 \\
PCB 194 & 0.01 & 0.02 & 0.07 & 0.08 & 0.04 & 0.05 \\
TOTAL PCBs & 0.45 & 1.82 & 7.42 & 8.09 & 4.48 & 4.78 \\
Mean & 0.035 & 0.140 & 0.571 & 0.622 & 0.345 & 0.368 \\
\hline
\end{tabular}




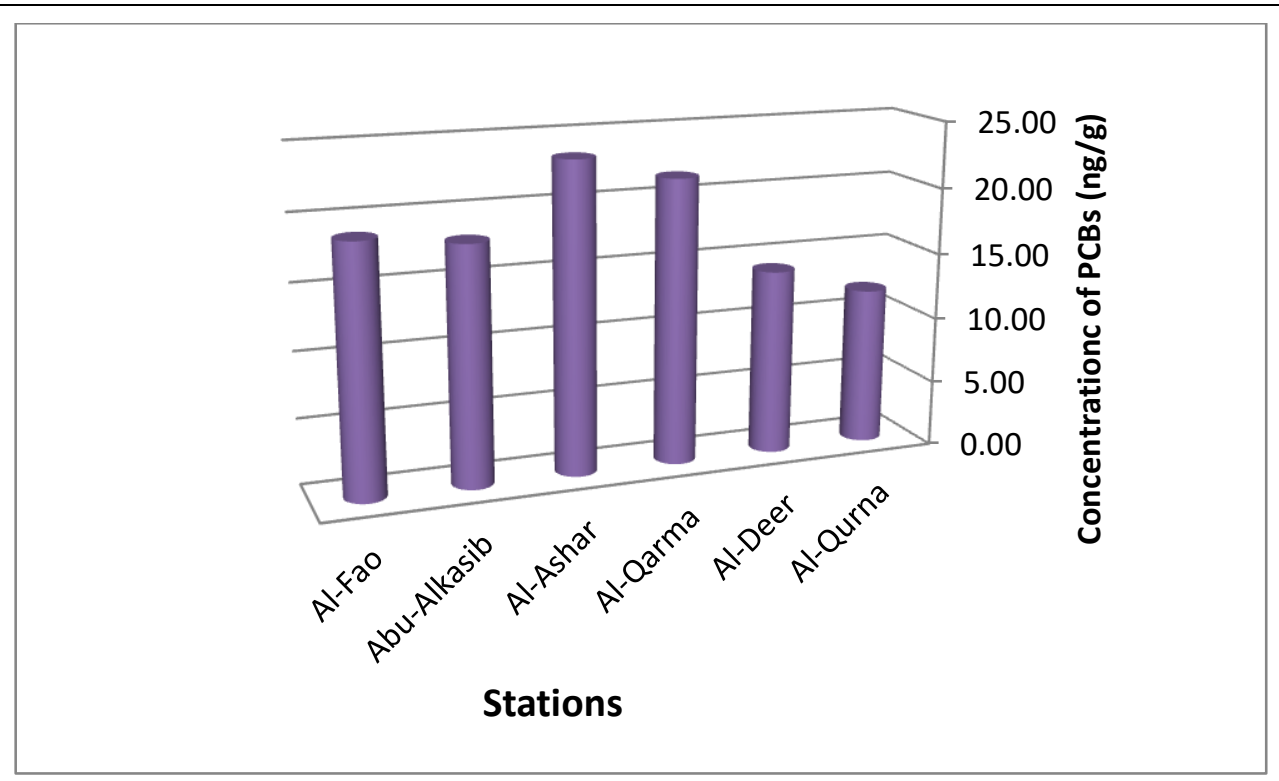

Figure (3): Regional Variations of the total concentrations of PCBs in Phragmites australis at study stations

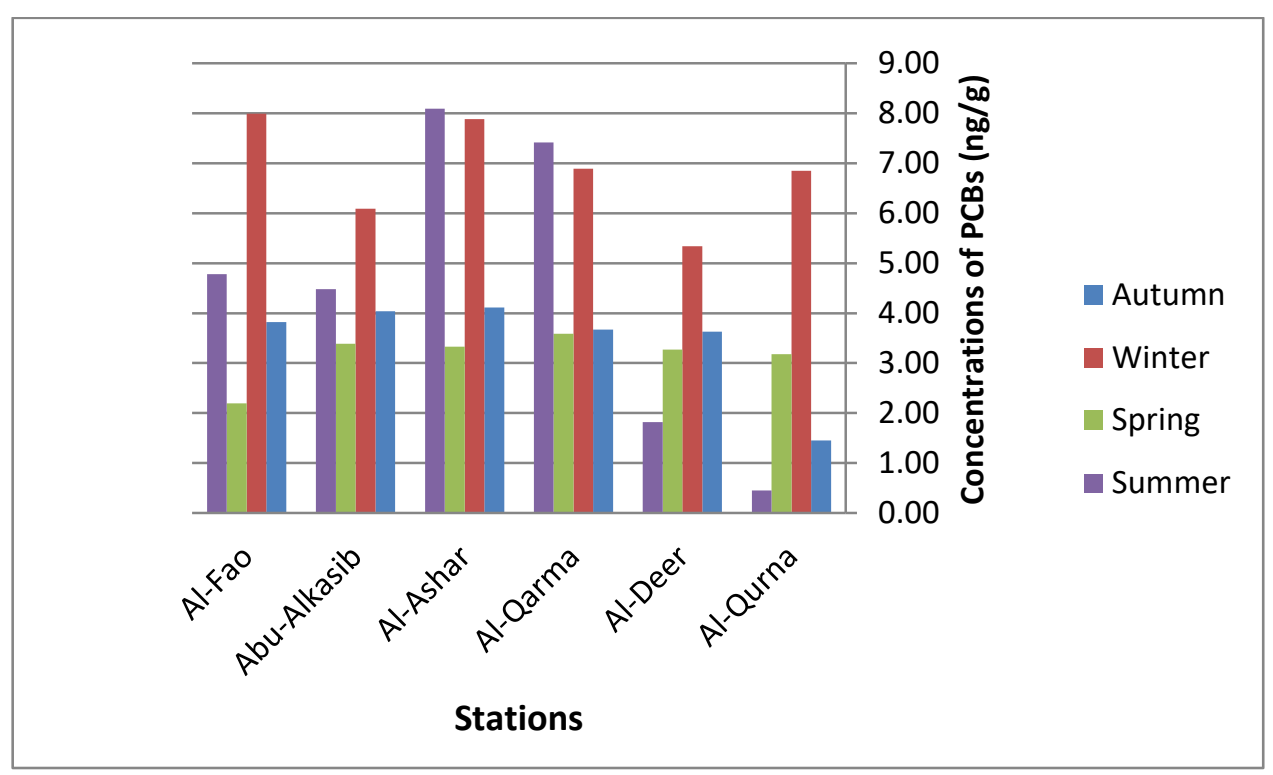

Figure (4): Total concentrations of PCBs Compounds in Phragmites australis at study stations 


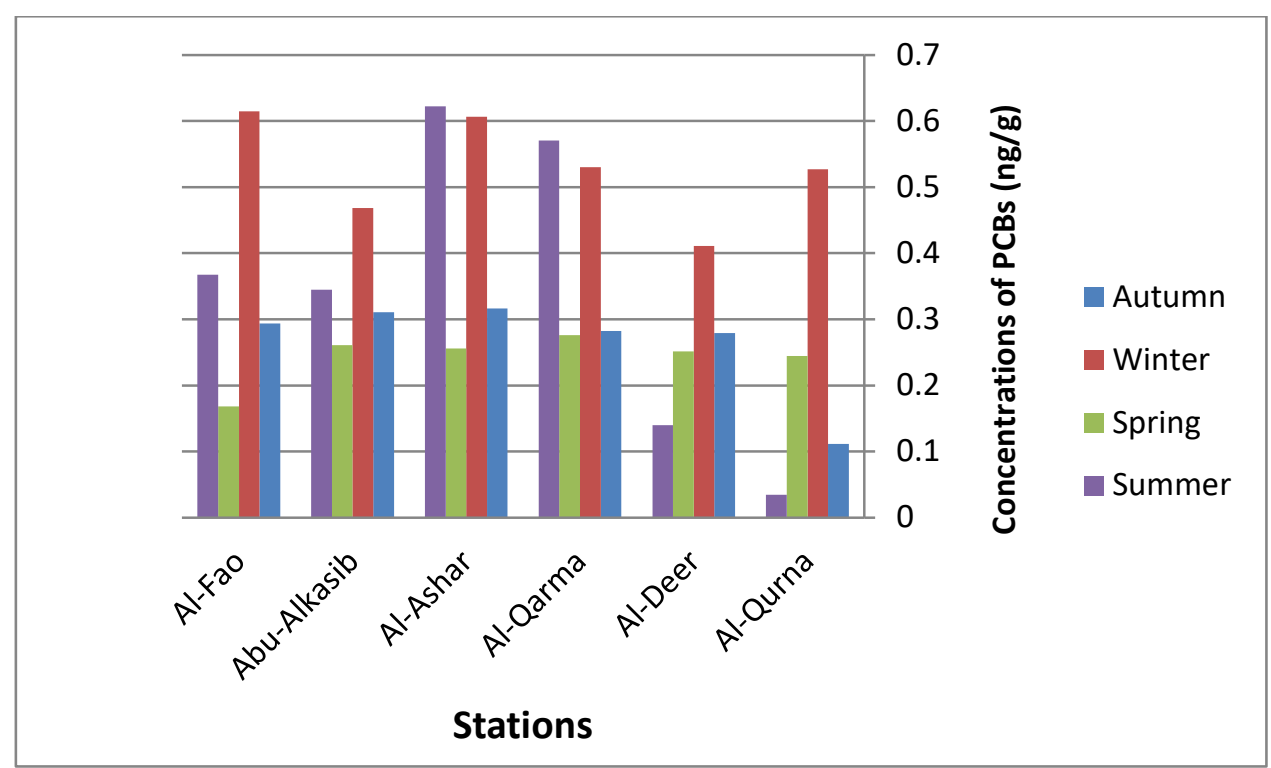

Figure (5): Mean of concentrations of PCBs Compounds in Phragmites australis at study stations

Significant differences $(\mathrm{P}>0.05)$ were not found among all stations, except PCB18. The highest mean value $(0.987 \mathrm{ng} / \mathrm{g})$ was recorded in Al-Ashar station, While Significant differences $(\mathrm{P}<0.05)$ were found among seasons for PCB18, PCB31, PCB44, PCB52, PCB141, PCB149, PCB138, PCB153 and PCB194 compounds, except PCB29, PCB28, PCB101, PCB189. The highest mean value (1.050ng/g) was recorded in winter for PCB18, The highest mean value $(0.426 \mathrm{ng} / \mathrm{g})$ was recorded in winter for PCB31, The highest mean value $(0.363 \mathrm{ng} / \mathrm{g})$ was recorded in winter for PCB44, The highest mean value $(0.701 \mathrm{ng} / \mathrm{g})$ was recorded in autumn for PCB52, The highest mean value $(1.290 \mathrm{ng} / \mathrm{g})$ was recorded in summer for PCB141, The highest mean value $(1.055 \mathrm{ng} / \mathrm{g})$ was recorded in winter for PCB149, The highest mean value $(0.776 \mathrm{ng} / \mathrm{g})$ was recorded in summer for PCB153 and the highest mean value $(0.818 \mathrm{ng} / \mathrm{g})$ was recorded in winter for PCB194.

There was a positive significant correlation between PCB18 and PCB194 $(r=0.491, \mathrm{P}<0.05)$, PCB153 ( $r=0.497, \mathrm{P}<0.05)$, PCB138 ( $\mathrm{r}=0.705, \mathrm{P}<0.01), \mathrm{PCB} 149(\mathrm{r}=0.691, \mathrm{P}<0.01)$ and PCB44 $(\mathrm{r}=$ $0.780, \mathrm{P}<0.01)$. A negative significant correlation was recorded between PCB31and between PCB153 $(\mathrm{r}=-0.448, \mathrm{P}<0.05)$ and a positive significant correlation with $\mathrm{PCB} 52(\mathrm{r}=0.619, \mathrm{P}<0.01)$ and $\mathrm{PCB} 44$ $(\mathrm{r}=0.423, \mathrm{P}<0.05)$. A positive significant correlation was recorded between $\mathrm{PCB} 28$ and between PCB189 $(r=0.471, \mathrm{P}<0.05)$. A positive significant correlation was recorded between PCB44 and between PCB194 ( $r=0.548, \mathrm{P}<0.01)$, PCB138 ( $r=0.496, \mathrm{P}<0.05), \mathrm{PCB} 149(\mathrm{r}=0.592, \mathrm{P}<0.01)$ and PCB18 $(r=0.780, P<0.01)$. A positive significant correlation was recorded between PCB52 and between PCB194 ( $\mathrm{r}=0.462, \mathrm{P}<0.05)$ and a negative significant correlation with $\mathrm{PCB} 141(\mathrm{r}=-0.516$, $\mathrm{P}<0.01)$. A positive significant correlation was recorded between PCB101and between PCB189 ( $\mathrm{r}=$ $0.530, \mathrm{P}<0.01)$. A positive significant correlation was recorded between PCB141 and between PCB153 $(\mathrm{r}=0.758, \mathrm{P}<0.01)$. A positive significant correlation was recorded between $\mathrm{PCB} 149$ and between PCB194 ( $\mathrm{r}=0.668, \mathrm{P}<0.01), \mathrm{PCB} 138(\mathrm{r}=0.849, \mathrm{P}<0.01)$ and $\mathrm{PCB} 18(\mathrm{r}=0.691, \mathrm{P}<0.01)$. A positive significant correlation was recorded between PCB138 and between PCB153 ( $r=0.694, P<0.01)$, PCB18 ( $\mathrm{r}=0.705, \mathrm{P}<0.01)$. A positive significant correlation was recorded between PCB153 and between PCB18 ( $\mathrm{r}=0.497, \mathrm{P}<0.05)$ and a positive significant correlation was recorded between PCB194 and between PCB18 $(r=0.491, \mathrm{P}<0.05)$. 
Pollution of water has been considered a critical environmental issue. The increasing exploitation of natural resources, the development of oil industries, refineries, domestic wastewater and industrial wastewater leads to the entry of chemical pollutants into aquatic ecosystems [22]. Among the most important pollutants of rivers, are hydrocarbons, consisting of thousands of chemicals in different physical forms and pose a great danger to aquatic life and lead to compound formations such as biphenyl [12]. PCBs congeners reach water bodies by runoff and/or air transport. In aquatic ecosystems, PCBs can bioaccumulate in the food chain by consuming contaminated water and organisms [9].

The Plants can absorb hydrocarbons from the water through their roots and transport them to other parts of the plant. Absorption rates are subject to many factors, including the concentration of compounds, solubility in water, physical and chemical status, and sediment type [31]. Some aquatic plants eliminate or reduce pollution levels through metabolic processes and lead to the removal or decomposition of various pollutants. As well as the secretion of enzymes present in the roots can lead to bioremediation processes [4]. According to the diversity of aquatic plants, their wide spread and good tolerance to environmental conditions, the Phragmites australis was used as a biomarker for studying water pollution [8].

Results of the present study showed the highest levels of PCBs in Phragmites australis during summer in Al-Ashar station, It may be attributed to that summer is the growing season of plants due to the high temperature and the long period of solar radiation. Therefore, the photosynthesis process will lead to an increase absorption of PCBs from the water and sediments $[15,16]$. In addition, industrial pollutants that discharge the pollutants directly, domestic waste and sewage disposal, which discharge from center of the Basrah city to the Shatt Al-Arab River through many channels, including AlKhandaq, Al-Ashar and Al-Khora channels [2]. The Phragmites australis absorbs compounds from water and sediments and stores of PCBs in its tissues, which leads to high concentrations of these compounds, so these aquatic plants have been used as biological indicators in aquatic ecosystems [10] and treatment of soils polluted with PCBs compounds [24]. As for the PCBs decrease during the summer in Al-Qurna station, it may be due the far distance to center of the Basrah city. As well as the low pollutants in this station may be due the low concentrations of PCBs in water in station, the high temperatures and evaporation increase during the summer. Therefore, PCBs decrease in water and lead to absorption decrease of PCBs by the plant and its decrease accumulation within the plant tissues, PCBs concentrations are related With the water temperature, The high temperature can be effect to removing most of the PCBs from the water [26]. Temperatures affect in two main directions, the first one is increase evaporation, in this process, carbon compounds with low molecular weights evaporate as well as the breakdown of carbon compounds which have high molecular weights [21]. The second affect of temperature increase the enzymatic activity of microorganism to breakdown PCBs compounds [25]. The current study confirmed and found a negative significant correlation between water temperature and PCBs compounds in plants. A negative correlation was recorded between water temperature and PCB194 ( $\mathrm{r}=-0.599, \mathrm{P}<0.01)$, PCB138 $(\mathrm{r}=-0.453, \mathrm{P}<0.05), \mathrm{PCB} 149 \quad(\mathrm{r}=-0.725$, $\mathrm{P}<0.01)$, PCB44 ( $\mathrm{r}=-0.542, \mathrm{P}<0.01)$ and $\mathrm{PCB} 18(\mathrm{r}=-0.407, \mathrm{P}<0.05)$.

The presence of rhizomes in Phragmites australis provides a large surface area for the breakdown of pollutants by bacteria, The root of the Phragmites australis also secretes peroxidase enzymes. These enzymes have the ability to decompose and convert some PCBs congeners with low chlorination degrees, while the highly chlorinated compounds were resistant to transformation or decomposition by plant enzymes [11]. Variations in the accumulation of PCBs pollutants in 
Phragmites australis may be due to some physical and chemical properties such as temperature, $\mathrm{pH}$, salinity, dissolved oxygen and nutrient concentrations in the surrounding environment [26], or due the special mechanisms for detoxification in the plant [13].

\section{Conclusion}

Phragmites australis is considered a bio indicator, It is found in rich organic matter and nutrients water. Therefore, Phragmites australis have the ability to reduce the concentrations of PCBs pollutants. The presence of rhizomes in Phragmites australis provides a large surface area for the breakdown of pollutants by bacteria The root of the Phragmites australis also secretes peroxidase enzymes, These enzymes have the ability to decompose and convert some PCBs congeners.

\section{Acknowlegement}

First and foremost, I would like to thank Allah for giving me force and health to complete this study. Sincerely, I would like to thank Prof. Dr. Hamid T. Al-Saad for the guidance, advice and continuous support. I would like to express my Special thanks to College of Sciences (Dept. of Biology) and Marine Science Center (Dept. of Environmental Chemistry and the staff of water quality laboratory) in University of Basrah.

\section{References:}

[1] Al-Abbawy, D. A. H., \& Al-Mayah, A. A. A. (2009). Influence of some ecological factors on plant tall, cover percent and biomass of Phragmites australis in marshes of southern Iraq after inundation. Marsh Bulletin, 121.

[2] Al-Hejuje, M. M. (2014). Application of water quality and pollution indices to evaluate the water and sediments status in the middle part of Shatt Al-Arab River. Ph. D. Thesis, Biology Department, College of Science, University of Basrah ....

[3] Al-Saad, H. T., Alhello, A. A., Al-Kazaeh, D. K., Al-Hello, M. A., Hassan, W. F., \& Mahdi, S. (2015). Analysis of water quality using physico-chemical parameters in the Shatt Al-Arab Estuary, Iraq. International Journal of Marine Science, 5.

[4] AL-Sanjari, M. N. F. (2011). The Efficiency of Phragmites australis in Wastewater Pretreatment. Tikrit Journal of Pure Science, 16(2).

[5] Apitz, S. E., Brils, J., Marcomini, A., Critto, A., Agostini, P., Micheletti, C., Pippa, R., Scanferla, P., Zuin, S., \& Lánczos, T. (2006). Approaches and frameworks for managing contaminated sediments-A European perspective. In Assessment and remediation of contaminated sediments (pp. 5-82). Springer.

[6] AZEEZ, N. M. (2021). Bioaccumulation and phytoremediation of some heavy metals ( $\mathrm{Mn}, \mathrm{Cu}, \mathrm{Zn}$ and $\mathrm{Pb}$ ) by bladderwort and duckweed. Biodiversitas Journal of Biological Diversity, 22(5).

[7] Barakat, A. O., Khairy, M., \& Aukaily, I. (2013). Persistent organochlorine pesticide and PCB residues in surface sediments of Lake Qarun, a protected area of Egypt. Chemosphere, 90(9), 2467-2476.

[8] Benabid, H., Ghorab, M. F., \& Djebaili, A. (2008). Cadmium as an environmental pollutant use of plant as bioindicator of pollution (invivo experimentation) influence of cadmium on chlorophyll content of Canadian wonder beans Phaseolus vulgaris. Research J. of Applied Science, 3(1), 66-69.

[9] Bjermo, H., Darnerud, P. O., Lignell, S., Pearson, M., Rantakokko, P., Nälsén, C., Barbieri, H. E., Kiviranta, H., Lindroos, A. K., \& Glynn, A. (2013). Fish intake and breastfeeding time are associated with serum concentrations of organochlorines in a Swedish population. Environment International, 51, 88-96.

[10] Cheng, S. (2003). Heavy metals in plants and phytoremediation. Environmental Science and Pollution Research, $10(5), 335-340$.

[11] Chu, W. K., Wong, M. H., \& Zhang, J. (2006). Accumulation, distribution and transformation of DDT and PCBsby Phragmites australis and Oryza sativa L.: II. Enzyme study. Environmental Geochemistry and Health, 28(1), 169- 
181. https://doi.org/10.1007/s10653-005-9028-7

[12] Esmaili, M. M., Ghanavati, Y. N., \& Ghanemi, K. (2015). Measurement of PCB Compounds in the Persian Gulf( Southern Pars Area ). 3(3), 316-320.

[13] Garcia, J., Rousseau, D. P. L., Morato, J., Lesage, E. L. S., Matamoros, V., \& Bayona, J. M. (2010). Contaminant removal processes in subsurface-flow constructed wetlands: a review. Critical Reviews in Environmental Science and Technology, 40(7), 561-661.

[14] Greipsson, S. (2011). Phytoremediation. Nature Education Knowledge 3 (10): 7 http://www. nature. com/scitable/knowledge/library/phytoremediatio n-... 1 of 5 1/1/2015 11: 41 PM. Figure, 2, 2.

[15] Hsu, S. (2004). Removal Polycyclic Aromatic Hydrocarbons (phenanthrene \& pyrene) in aquatic phase by Ceratophylum demorsum \& Naja gramunea. Master thesis. Marine Environment \& Engineering. chinese.

[16] Jazaa, S. H. (2009). A study of physical, chemical and bacteriological properties of water of Al-Kahlaa river in maysan governorate/Iraq. M. Sc. Thesis. College of Science. University of Basrah. pp: 67.

[17] Klaren, W. D., Gadupudi, G. S., Wels, B., Simmons, D. L., Olivier, A. K., \& Robertson, L. W. (2015). Progression of micronutrient alteration and hepatotoxicity following acute PCB126 exposure. Toxicology, 338, 1-7.

[18] Li, Q., Luo, Z., Yan, C., \& Zhang, X. (2011). Assessment of polychlorinated biphenyls contamination in sediment and organism from Xiamen offshore area, China. Bulletin of Environmental Contamination and Toxicology, 87(4), $372-376$.

[19] Li, Y., Lin, T., Qin, Y., Zhang, L., \& Guo, Z. (2013). Distribution and sources of organochlorine pesticides in sediments of the Xiangjiang River, south-central China. Environmental Monitoring and Assessment, 185(11), 88618871.

[20] Ludewig, G., \& Robertson, L. W. (2013). Polychlorinated biphenyls (PCBs) as initiating agents in hepatocellular carcinoma. Cancer Letters, 334(1), 46-55.

[21] Lyons, B. P., Barber, J. L., Rumney, H. S., Bolam, T. P. C., Bersuder, P., Law, R. J., Mason, C., Smith, A. J., Morris, S., Devlin, M. J., Al-enezi, M., Massoud, M. S., Al-zaidan, A. S., \& Al-sarawi, H. A. (2015). Baseline survey of marine sediments collected from the State of Kuwait: PAHs, PCBs, brominated fl ame retardants and metal contamination. $M P B, 100(2), 629-636$. https://doi.org/10.1016/j.marpolbul.2015.08.014

[22] Mills, L. J., \& Chichester, C. (2005). Review of evidence: are endocrine-disrupting chemicals in the aquatic environment impacting fish populations? Science of the Total Environment, 343(1-3), 1-34.

[23] Rahuman, M., Pistone, L., Trifirò, F., \& Miertus, S. (2000). Destruction technologies for polychlorinated biphenyls (PCBs). Proceedings of Expert Group Meetings on POPs and Pesticides Contamination, 16(6), 405-423.

[24] Schwitzguébel, J.-P., Page, V., Martins-Dias, S., Davies, L. C., Vasilyeva, G., \& Strijakova, E. (2011). Using plants to remove foreign compounds from contaminated water and soil. In Organic Xenobiotics and Plants (pp. 149-189). Springer.

[25] Shamshoom, S. M., Ziara, T., Abdul-Ritha, A. N., \& Yaacoub, A. E. (1990). Distribution of oil degrading becteria in NW Arabian Gulf. Mar. Poll. Bull, 21, 38-40.

[26] Thomas, R. G. (1982). Volatilization from water. Handbook of Chemical Property Estimation Methods, 15.

[27] Vorkamp, K., Roose, P., Bersuder, P., Webster, L., Lepom, P., \& Munschy, C. (2012). ICES T ECHNIQUES IN M ARINE E NVIRONMENTAL S CIENCES N O . 50 M AY 2012 Determination of polychlorinated dibenzo-p -dioxins, polychlorinated polychlorinated biphenyls in biota and sediment.

[28] Wei, Z., Van Le, Q., Peng, W., Yang, Y., Yang, H., Gu, H., Lam, S. S., \& Sonne, C. (2021). A review on phytoremediation of contaminants in air, water and soil. Journal of Hazardous Materials, 403, 123658. https://doi.org/https://doi.org/10.1016/j.jhazmat.2020.123658

[29] Wenerick, W. R., Stevens, S. E., Webster, H. J., Stark, L. R., \& DeVeau, E. (2020). Tolerance of three wetland plant species to acid mine drainage: a greenhouse study. In Constructed wetlands for wastewater treatment (pp. 801-807). CRC Press.

[30] Zhang, J., Qiu, L., Jia, H. E., Yuan, L., \& Luo, Y. (2007). Occurrence and congeners specific of polychlorinated biphenyls in agricultural soils from Southern Jiangsu, China. Journal of Environmental Sciences, 19(3), 338-342.

[31] Zhong, Y., Luan, T., Lin, L., Liu, H., \& Tam, N. F. Y. (2011). Production of metabolites in the biodegradation of phenanthrene, fluoranthene and pyrene by the mixed culture of Mycobacterium sp. and Sphingomonas sp. Bioresource Technology, 102(3), 2965-2972. 